\title{
PARASITIC ACTIVITY OF POWDERY MILDEW (PATHOGEN STRAIN HMLAC226) ON PROSTRATE KNOTWEED (POLYGONUM AVICULARE L.) AT VARIOUS LOCATIONS OF SHENYANG, NORTHEAST CHINA
}

\author{
IQBAL, M. F. ${ }^{1,2}-$ FenG, Y. L. ${ }^{1 *}-$ LiU, M. C. ${ }^{1}-$ LU, X. R. ${ }^{1}-$ NASIR, M. ${ }^{3}-$ SiKANDAR, A. ${ }^{4}$ \\ ${ }^{l}$ College of Bioscience and Biotechnology, Shenyang Agricultural University No. 120 Dongling \\ Road, Shenyang, Liaoning Province 110866, China \\ ${ }^{2}$ Department of Agriculture, Adaptive Research Farm, Gujranwala, Punjab, Pakistan \\ ${ }^{3}$ Plant Protection Department, Institute of Cotton Research, CAAS, Anyang, Henan, China \\ ${ }^{4}$ Nematology Institute of Northern China, No. 120 Dongling Road, Shenyang, Liaoning \\ Province 110866, China \\ *Corresponding author \\ e-mail:yl_feng@tom.com; phone: +86-24-8848-7163; fax: +86-24-8849-2799
}

(Received 13 $3^{\text {th }}$ Jun 2019; accepted $28^{\text {th }}$ Aug 2019)

\begin{abstract}
Prostrate knotweed (Polygonum aviculare L.) is a persistent native weed of China. This weed is characterized by high genetic and biological plasticity having a capacity to spread on a landscape scale. The present study planned to investigate the infection of a plant parasitic powdery mildew on $P$. aviculare on a landscape scale in three different locations of Shenyang during 2018. These locations were selected with a control treatment for proper comparison. Different growth parameters were observed and calculated by coefficient of determination $\left(R^{2}\right)$. Maximum temperature (Maxt) ranged $25-30{ }^{\circ} \mathrm{C}$ and Minimum temperature (Mint) between $17-20{ }^{\circ} \mathrm{C}$ with relative humidity $64-78 \%$ played a vital role for the emergence and flourishing of pathogen pressure on the plant. The elevated value of $R^{2}=0.97$ for Mint with RMSE (Root Mean Square Error) $<5$ recorded excellent prediction followed by $R^{2}=0.82$ with RMSE $<5-10$ for Maxt recorded very good model prediction. Highly significant $(\mathrm{P}<0.001)$ height of Polygonum aviculare was recorded $(23.125 \pm 0.59)$ in parasite free plants compared to $(20.99 \pm 0.96)$ location-I having Mean $\pm \mathrm{SD}$. Both temperature ranges has a significant effect $(\mathrm{P}<0.0001)$ with $(\mathrm{F}=5.917 ; \mathrm{P}<0.0001 ; \mathrm{F}=25.721 ; \mathrm{P}<0.0001)$ three locations; however, the effect of the locations on plants height ( $P$. aviculare) did not differ statistically $(\mathrm{F}=2.102 ; \mathrm{P}>0.05)$ between two temperature ranges from $25-30{ }^{\circ} \mathrm{C}$ and $17-20^{\circ} \mathrm{C}$. According to our findings, plant parasitic powdery mildew (pathogen strain HMLAC226) affected significantly with growth characteristics of prostrate knotweed.
\end{abstract}

Keywords: ecology, landscape, native plant, transect method, Liaoning-Province

\section{Introduction}

Prostrate knotweed (Polygonum aviculare L.) is an annual native weed to Europe, introduced in China during 2004 (Coquillat, 1951; Flora, 2004; Ma et al., 2013), initially collected in Canada in 1821 and widespread in the globe (Costea and François, 2005). Its extensive distribution is credited to elevated genetic polymorphism and phenotypic agility (Meerts, 1995) and spread in soyabean, rice, maize, sweet potato, cotton, sugarcane, orchards and other agricultural crops (Tottman and Wilson, 1990). This weed grows in poorly aerated heavy compacted soil with $3.5 \mathrm{pH}$ (You et al., 2005). P. aviculare L. belongs to Polygonaceae family grow up to $30.50-91 \mathrm{~cm}$ long with tiny elliptic lanceolate 
foliage. Its foliage is opposite, lance form to rectangle and $12.50-63.50 \mathrm{~mm}$ elongated, silver, papery casing at every nodule, flowers are present in the groups in clusters (Severoglu et al., 2012). Due to its taproot system, the roots of full-grown plants reached up to $70 \mathrm{~cm}$ in alluvial soils. However, thick parallel inferior roots were dispersed in the upper segment (15-25 cm) of soil (Costea and François, 2005).

Prostrate knotweed seeds require moist-cold stratification for germination (Batlla et al., 2009). The seeds of this weed lose dormancy in March and April and germinate in a single flush between March and May. Its flowers are hermaphroditic and self pollinated (Meerts et al., 1990). In California, more than 36 insect taxa were documented to feed on the nectar of this weed; however, both above ground and terrestrial insects were attracted on the flowers (Bugg et al., 1987).

Recently many studies that endeavour to work out the fiscal worth of the ecosystem services provided by plant life have paid their attention on both native and deliberately cultured landscapes floral communities (Bolund et al., 1999; Chen et al., 2008; Tyrväinen et al., 2005). Now the ecologists approach to understand that an assessable level of ecological functionality can be accomplished by a sophisticated collection of species (Hobbs et al., 2009; Pickett et al., 2008). At the functional level, natural urban flora can be measured and prolonged in the logic that it is performing an extensive assortment of experimental ecosystem services on subsidiary terra firma with a negligible contribution of continuation possessions (Rink, 2009; Del and Peter, 2010).

Powdery mildews (Erysiphe polygoni; Erysiphales family Erysiphaceae) are significant cluster of fungi, capable for causing diseases in natural flora. This pathogen has 873 species with 17 genera (Braun, 2012) attack on 10,000 species of angiosperms in the world (Braun, 2012). The most imperative, key pervasive and easily predictable invasive pathogen of prostrate knotweed ( $P$. Aviculare) is powdery mildew (Erysiphe polygoni), strain HMLAC226, gene JN621872 through DQ490766 ITS sequence present in Mengyin, Shandong, China (Pintye et al., 2012). The attack symptoms are grayish-white, powdery mat visible on the upper surface of leaves (Abkhoo, 2009). The pathogen reduce photosynthesis, increase respiration, transpiration, and or caused the growth retarded (Severoglu et al., 2012).

The fungal spores shifted through air to the newly introduced host plant and its growth started on epidermal cells of the leaf by means of haustoria (Carlile et al., 2001) and put the haustoria into mesophyll cells of prostrate knotweed (Takamatsu et al., 1998). However, moderate temperature and humidity (\%) played a significant role for flourishing and spreading pathogen infection (Koike et al., 2007) that becomes the base of significant loss to the landscape of China.

The article aimed to determine parasitic powdery mildew (pathogen strain HMLAC226) on certain physiological characteristics of prostrate knotweed. These characteristics studied at different temperatures ranges and in various locations of Shenyang using determination coefficient $\left(R^{2}\right)$ and Root Mean Square Error (RMSE) under Liaoning Key Laboratory for Biological Invasions and Global Changes, College of Bioscience and Biotechnology, Shenyang Agricultural University, Shenyang China.

\section{Materials and methods}

\section{Experimental site}

The studied areas northern part in China having the hilly area that edges into South Korea. During survey we selected three locations randomly (location I having latitude 
$41^{\circ} 49.490 \mathrm{~N}$ and longitude $=123^{\circ} 35.397 \mathrm{E}$; location II having latitude $41^{\circ} 48.851 \mathrm{~N}$ and longitude $=123^{\circ} 33.464 \mathrm{E}$; location III having latitude $41^{\circ} 49.760 \mathrm{~N}$ and longitude $=123^{\circ}$ $34.141 \mathrm{E}$ ) respectively (Fig. 1B). Maximum annual temperature (Maxt) ranges between (8.30 to $36.10{ }^{\circ} \mathrm{C}$ ) and minimum (Mint) -32.90 to $12.40{ }^{\circ} \mathrm{C}$ but the annual rainfall was $698.5 \mathrm{~mm}$ with relative humidity $62-78 \%$ (Fig. 1A).
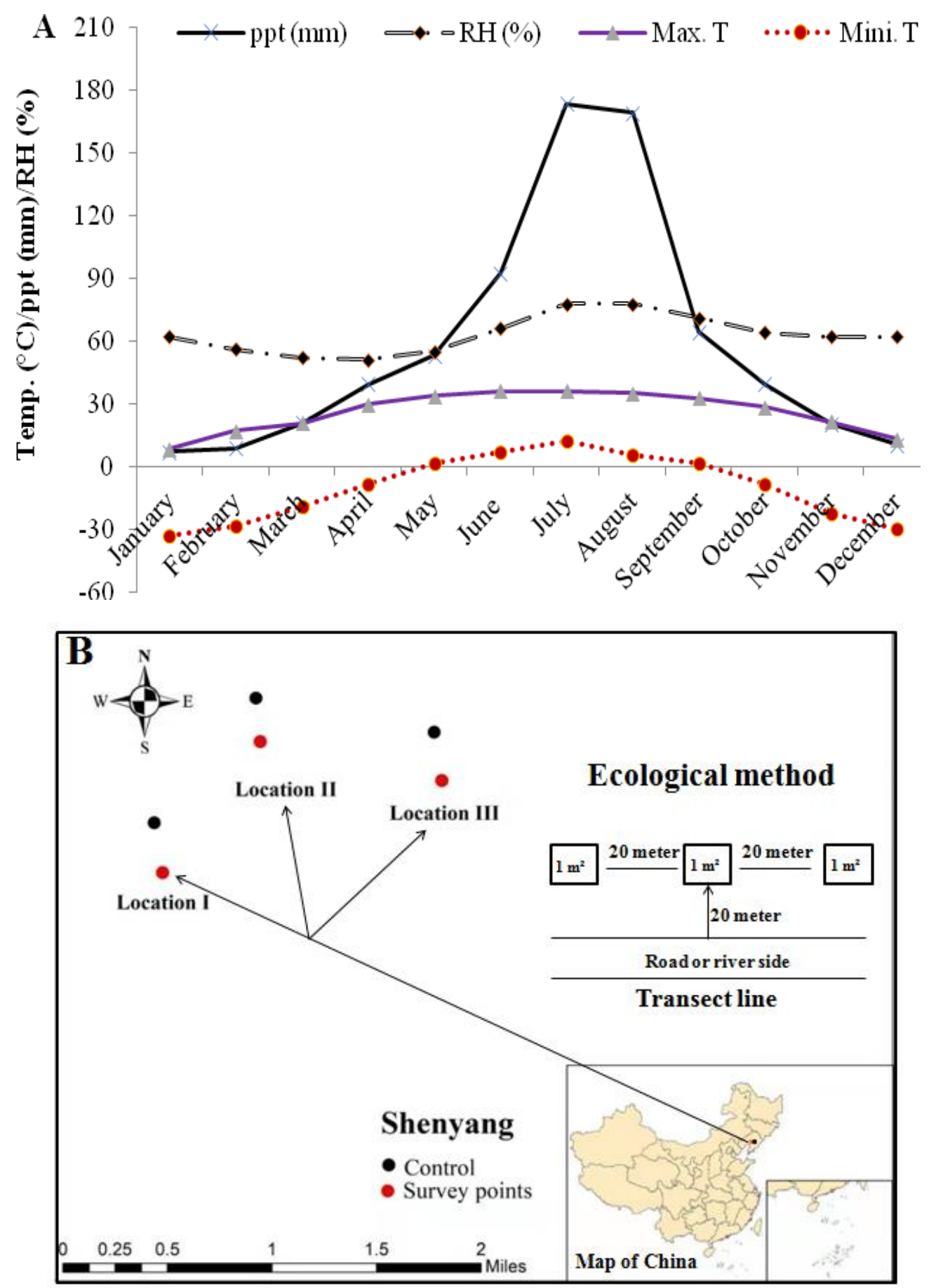

Figure 1. (A) Monthly climatic data of Shenyang for the year 2018 (data sourced from Chinese meteorological data base). (B) Three studied locations and control was the average of these three locations using mapping software ESRI (ArcGis, 2013) and $1 \mathrm{~m}^{2}=$ one square meter 


\section{Experimental design}

Ecological survey was conducted in three locations of Shenyang by line transect ecological method of sampling in field conditions during 2018. During ecological survey in July, prostrate knotweed leaves infected with powdery mildew (Erysiphe polygoni) and its pathogen strain HMLAC226 was selected. The transect line was sixty meter long parallel to the roadside and collected three points twenty meters in one side of the transect (Fig. 1B) and data were recorded using quadratic methods $(100 \times 100$ $\mathrm{cm})$. Control point was also selected in these three locations having three replications at each location in same environmental cues. The selected surveyed points were observed during peak season for three weeks and temperature data were recorded on the spot and calculated. However, after collection of the temperature data from three locations, maximum and minimum temperature was calculated. Three whole knotweed plants in each quadratic ring were selected randomly and uprooted keeping in view no any part of the plant was damaged by external or physical injury. A sum total of nine plants collected from three quadratic rings from each sampling point, uprooted along with control plants or pathogen free plants (selected from close observations), taken in the laboratory for measuring its growth parameters and other characteristics. Control plants were the average of disease free plants collected within three locations. The initial pathogen symptoms were present on the leaves just like dusted flour. Powdery mildew usually starts off as circular, powdery white spots, which can appear on leaves, stems of the plant. However, control plants or pathogen free plants were selected from the same environmental conditions near to the infected community of knotweed populations.

\section{Pathogen identification}

Powdery mildew-infected leaves of $P$. aviculare from these three locations and examined under microscope under microscope (Olympus DP 80 model) with the magnification of $20 \mu \mathrm{m}$ and $200 \mu \mathrm{m}$. The spore slides were prepared using cedar wood oil (artificial, Shanghai specimen model factory, China) which was pale-yellow to yellow in color. The drops solution of this oil was xylene based with acid value $<60 \mathrm{mg}$ $\mathrm{KOH} \mathrm{\textrm {g } ^ { - 1 }}$ was used and identified the pathogen with the help of available literature (Braun, 1987; Braun and Takamatsu, 2000; Braun et al., 2003) on morphometric characteristics of the pathogen (Fig. 2).

\section{Growth parameter measurement}

Plant height $(\mathrm{cm})$, root length $(\mathrm{cm})$, number of lateral and main branches was measured; however, all leaves were removed separately from randomly selected nine plants from each sampling point. The leaf area was measured by destructive method (Ahmad et al., 2015; Aldesuquy et al., 2014).

\section{Re-modification of the evolving model}

The regression-type relationship carried out for developing the model for treatments and comparison of RMSE with $R^{2}$. The regression model was set out to determine the effect of different growth parameters ultimately gave the information about model fitness of how far away the fitted line is from the reference line. The researchers previously exposed that how condensed or scattered the observed points are around the fitted line, which alternatively revealed about the validity and good-fit of the model 
(Hossain et al., 2017). For the evaluation of different growth parameters in an experiment with $\mathrm{n}$ observations and agreement between predicted and actual values was purposed with root mean square error (RMSE) that was defined by Equation 1 (Debaeke et al., 1997; Ahmed et al., 2019).

$$
R M S E=\sqrt{1 / n \times \sum_{j=1}^{n}\left(\left(\text { Yield }_{\text {mes }}-\text { Yield }_{\text {sim }}\right)^{2}\right.}
$$

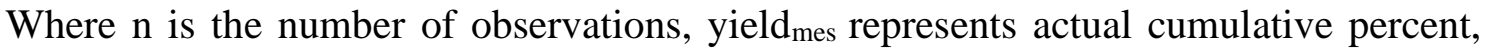
yield $_{\text {sim }}$ is predicted cumulative percentage (Mayer and Butler, 1993). RMSE gave a magnitude of the characteristic variation between predicted and actual values. The RMSE categorized to assess the precision of the model (Royo et al., 2010) reported that RMSE < 5 means awesome prediction; 5-10, very good prediction; 10-15, good prediction; > 15, inadequate prediction. The lowest RMSE designated the appearance of the model fitness had optimized.

\section{Statistical analyses}

The above ecological indices were focused on analysis of variance through invasion condition at different locations with analysis of variance (ANOVA) test. The mean differences between locations growth characters were calculated using Tukey's HSD (Honest Significance Test), post hoc on Fishers's LSD test, these tests were performed using SPSS statistical software (version 13.0; Inc., Chicago, IL, USA) and R (version 3.3.1) package (Nigussie et al., 2017; Rcore, 2016). The geographic coordinates were recorded using GPS navigator and map of the studied locations was designed by ArcGIS version 10.2 software (ArcGis, 2013).

\section{Results}

The data recorded highly significant $(\mathrm{P}<0.001)$ plant height of $P$. aviculare in uninfected powdery mildew control $(23.125+0.59)$ compared to $(20.99 \pm 0.96)$ location-I, location-II (19.42 \pm 0.53$)$ having Mean \pm SD. Statistically highly significant $(\mathrm{P}<0.0001)$ root length $(\mathrm{cm})$ was recorded in control treatment $(21.08 \pm 0.40)$ comparable with location-I $(18.87 \pm 0.80)$ recording significant result $(\mathrm{P}<0.01)$. Leaf area $\left(\mathrm{cm}^{2}\right)$, number of main branches and number of lateral branches differed significantly $(\mathrm{P}<0.01)$ in control compared to other but illustrated non-significant $(\mathrm{P}>0.05)$ result with rest of locations at Shenyang (Table 1). The experiment deliberated that the effectiveness of powdery mildew (Erysiphe polygoni) significantly reduced the plant height, root length, leaf area and lateral branches significantly; but do not differ statistically with main branches of the selected prostrate knotweed $(P$. aviculare).

Different growth parameters calculated by co-efficient of determination $\left(R^{2}\right)$. The studied maximum temperature (Maxt) ranged $25-30{ }^{\circ} \mathrm{C}$, minimum temperature (Mint) between $17-20^{\circ} \mathrm{C}$ with relative humidity $64-78 \%$ was played a significant role for the emergence and flourishing of pathogen pressure on the plant; however, elevated value of $R^{2}=0.97$ for Mint with RMSE $<5$ recording awesome model prediction followed by $R^{2}=0.82$ with RMSE $<5-10$ for Maxt recording very good model prediction (Table 2). 


$$
\text { - } 13388 \text { - }
$$

Table 1. Effect of different growth parameters of Polygonum aviculare L. at different locations

\begin{tabular}{c|c|c|c|c|c}
\hline Weed & $\begin{array}{c}\text { Plant height } \\
(\mathbf{c m})\end{array}$ & $\begin{array}{c}\text { Root length } \\
(\mathbf{c m})\end{array}$ & $\begin{array}{c}\text { Leaf area } \\
\left(\mathbf{c m}^{\mathbf{2}}\right)\end{array}$ & Main branches & $\begin{array}{c}\text { Lateral } \\
\text { branches }\end{array}$ \\
\hline Control & $23.125 \pm 0.59^{\mathrm{a}}$ & $21.08 \pm 0.40^{\mathrm{a}}$ & $2.71 \pm 0.31^{\mathrm{a}}$ & $7.63 \pm 0.74^{\mathrm{a}}$ & $3.38 \pm 0.52^{\mathrm{a}}$ \\
Location-I & $20.99 \pm 0.96^{\mathrm{b}}$ & $18.87 \pm 0.80^{\mathrm{b}}$ & $2.42 \pm 0.14^{\mathrm{b}}$ & $7.00 \pm 0.76^{\mathrm{a}}$ & $2.50 \pm 0.53^{\mathrm{b}}$ \\
Location-II & $19.42 \pm 0.53^{\mathrm{c}}$ & $16.18 \pm 1.00^{\mathrm{c}}$ & $2.32 \pm 0.14^{\mathrm{b}}$ & $6.88 \pm 0.64^{\mathrm{a}}$ & $2.50 \pm 0.53^{\mathrm{b}}$ \\
Location-III & $19.84 \pm 1.00^{\mathrm{c}}$ & $16.26 \pm 1.04^{\mathrm{c}}$ & $2.30 \pm 0.15^{\mathrm{b}}$ & $7.38 \pm 0.52^{\mathrm{a}}$ & $2.63 \pm 0.52^{\mathrm{b}}$ \\
C. V. & 0.57 & 2.24 & 0.003 & 0.016 & -0.03 \\
S.E. & 0.217 & 0.336 & 0.050 & 0.133 & 0.104 \\
LSD & $\mathrm{P}<0.001$ & $\mathrm{P}<0.001$ & $\mathrm{P}<0.01$ & $\mathrm{P}>0.05$ & $\mathrm{P}<0.05$ \\
\hline
\end{tabular}

C.V. = component variance; the same letter do not differ statistically from each other at $5 \%$ significance level $(\mathrm{P}>0.05)$; however, means having different letters indicated statistically significant result $(\mathrm{P}<0.05)$ or $(\mathrm{P}<0.01)$ or $(\mathrm{P}<0.001), \quad \mathrm{LSD}=$ least significant Difference; (mean $\pm \mathrm{SD}), \quad \mathrm{S}$. D. $=$ standard deviation, S.E. $=$ standard error

Table 2. Regression model for growth parameter of Polygonum aviculare L. showing comparison of co-efficient determination $\left(R^{2}\right)$ with RMSE during 2018

\begin{tabular}{c|c|c|c}
\hline Weed & Regression model & $\boldsymbol{R}^{2}$ & RMSE \\
\hline Prostrate knotweed & $\mathrm{PH}=-0.5769 \times \mathrm{H}+21.24$ & 0.50 & 20.17 \\
(P. aviculare L.) & $\mathrm{Rl}=-1.5488 \times \mathrm{R}+22.482$ & 0.42 & 51.16 \\
& $\mathrm{LA}=7.4975 \times \mathrm{A}+0.5067$ & 0.35 & 26.94 \\
& $\mathrm{Mb}=0.1875 \times \mathrm{M}+6.7083$ & 0.52 & 1.75 \\
& $\mathrm{Lb}=0.0625 \times \mathrm{L}+2.4167$ & 0.75 & 0.11 \\
& $\mathrm{Maxt}\left({ }^{\circ} \mathrm{C}\right)=0.93 \times \mathrm{Ma}+26.069$ & 0.82 & 8.55 \\
& Mint. $\left({ }^{\circ} \mathrm{C}\right)=1.4375 \times \mathrm{Mi}+15.547$ & 0.97 & 4.28 \\
\hline
\end{tabular}

$\mathrm{PH}=$ plant height; $\mathrm{Rl}=$ root length; $\mathrm{LA}=$ leaf area; $\mathrm{Mb}=$ number of main branches; $\mathrm{Lb}=$ number of lateral branches; Maxt $=$ maximum temperature; Mint $=$ minimum temperature; $R^{2}=$ coefficient of determination; RMSE = root mean square error

However, the value of $R^{2}=0.75$ with $\mathrm{RMSE}=0.11$ described strong model fitting in the experiment. The polynomial relationship for number of main branches also displayed a linear arc pattern which strung with an initial linear stage followed by moderate asymptotic trend at the growth stage by $R^{2}(0.52)$ with RMSE (1.75) indicated the good model prediction. The values more than 15 indicated insufficient prediction of the model fitness. Maximum, minimum temperature was effecting significantly $(\mathrm{F}=5.917 ; \mathrm{P}<0.0001 ; \mathrm{F}=25.721 ; \mathrm{P}<0.0001)$; however, the interaction between location with height of the $P$. aviculare did not differ statistically $(\mathrm{F}=2.102 ; \mathrm{P}>0.05)$ between two temperature ranges from $25-30{ }^{\circ} \mathrm{C}$ and $17-20{ }^{\circ} \mathrm{C}$ (Table 3). The root length of the $P$. aviculare was affected highly significant $(\mathrm{F}=54.41 ; \mathrm{P}<0.0001)$ with height and locations showed its plasticity but there interaction $(\mathrm{PH} \times \mathrm{L})$ to total variance was strongly trait specific recording non-significant result $(\mathrm{F}=3.796 ; \mathrm{P}>0.05)$.

The plant height was recorded significant result $(\mathrm{F}=3.796 ; \mathrm{P}<0.05)$ with leaf length; however, plant height showed high significant $(\mathrm{F}=7.900 ; \mathrm{P}<0.001)$ result with location. The interaction between leaf length and location $(\mathrm{Ll} \times \mathrm{L})$ with height $(F=0.579 ; P>0.05)$ did not correlated statistically; however, it was also a trait specific. 


$$
\text { - } 13389 \text { - }
$$

Table 3. Analysis of variance of the interaction of maximum, minimum temperature, with location, plant height, leaf length of $P$. aviculare on four locations during 2018

\begin{tabular}{c|c|c|c|c}
\hline Parameter & Source & d.f. & MS & $\boldsymbol{F}$ \\
\hline \multirow{4}{*}{ Maxt } & Location (L) & 2 & 10.778 & $5.917^{* * *}$ \\
& Plant height (PH) & 1 & 3.828 & $2.102 \mathrm{NS}$ \\
& L x PH & 2 & 1.514 & $0.831 \mathrm{NS}$ \\
\hline \multirow{3}{*}{ Mint } & L & 2 & 18.111 & $25.721^{* * *}$ \\
& PH & 1 & 0.193 & $0.274 \mathrm{NS}$ \\
& L x PH & 2 & 0.399 & $0.567 \mathrm{NS}$ \\
\hline \multirow{3}{*}{ Rl } & PH & 1 & 66.82 & $54.141^{* * *}$ \\
& L & 2 & 20.18 & $16.353^{* * *}$ \\
& PH x L & 2 & 1.13 & $0.912 \mathrm{NS}$ \\
\hline \multirow{3}{*}{ PH } & Ll & 1 & 2.483 & $3.796^{*}$ \\
& L & 2 & 5.167 & $7.900^{* *}$ \\
& Ll x L & 2 & 0.379 & $0.579 \mathrm{NS}$ \\
\hline
\end{tabular}

The range of maximum temperature $=$ Maxt. was $25-30^{\circ} \mathrm{C}$ and minimum temperature $=$ Mint. was $17-$ $20^{\circ} \mathrm{C}$; location $=\mathrm{L}$; plant height $=\mathrm{H}$; Leaf length $=\mathrm{Ll}$ in northeast regions. For each effect, we show the mean square (MS); degree of freedom (DF); $\mathrm{F}$ and $\mathrm{P}$ value. Significance level is $\mathrm{P}>0.05$

The fresh leaves infected with powdery mildew scrapped off gently into small pieces. These infected leaves were examined under microscope. In our study, the first symptoms visible as powdery white scraps on the upper portion of foliage further developed to plentiful hyphal development on the upper and lower sides of the leaves (Fig. 2a). Infected leaves become chlorotic with warped periphery resulted in early defoliation. Hyphal appressoria were well developed, lobed (Fig. 2d) and present in opposed pairs (Fig. 2).

Cleistothecium was emerged and conidiophores appeared cylindrical and appressorium was observed and identified on $200 \mu \mathrm{m}$ (Fig. 2c, 2d). The cells of conidiophores formed in a round straightway in shape. The conidia produced in the single oval-shaped round to oblong. Germ tubes recorded in the perihilar portion of conidia and identified with $20 \mu \mathrm{m}$ magnification under microscope (Fig. 2b).

\section{Discussion}

The study regarding parasitic activity of powdery mildew (Erysiphe polygoni L.) having its pathogen strain HMLAC226 recorded on native prostrate knotweed (Polygonum aviculare L.) investigated best prediction model of coefficient of determination $\left(R^{2}\right)$. These results correlated with previously explicated investigations that leaf area measured in grassland exposed good performance $R^{2}=0.88$ with RMSE $=0.96$ (Francone et al., 2014).

Our results were in accordance to the researchers who reported that stable temperature models were accustomed to predict the evolution under changing temperatures. However, the pathogen development pressure reduced quickly at elevated temperatures than at lower temperatures comparable to optimum temperature (Xu, 1999). 
The temperature effect in this experiment are in line with the researchers who reported in their experiments that the prevalence of powdery mildew propelled by moderate temperatures $\left(21-30{ }^{\circ} \mathrm{C}\right)$. Elevated temperatures can delay or stop the growth and spore formation of Erysiphe. Vulnerability of times depleted increases with elevated temperature, maximum temperature ranged between $22-27{ }^{\circ} \mathrm{C}$ played a vital role for the germination of conidia (Peduto et al., 2013).
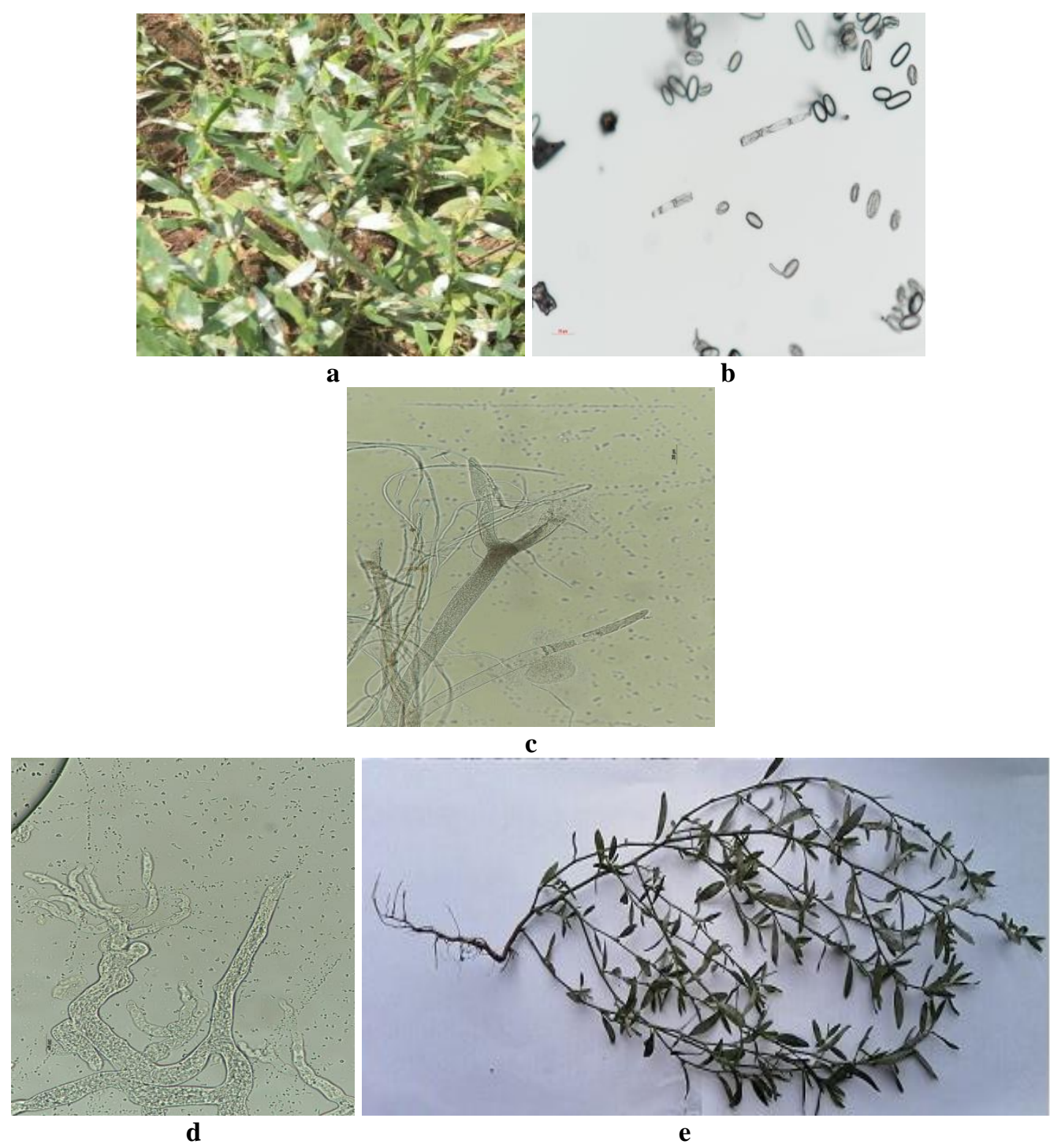

Figure 2. Different stages of powdery mildew infection on Polygonum aviculare a. Infection; $b$. germ tube; c. Cleistothecium, Conidiophore; d. Appressorium; e. Healthy plant

Exclusive growth models were fit to the expansion rate data with high significance value (Miller et al., 2003). As well as lower rate of development, supra-optimal temperatures resulted in higher spores mortality and faster rate at which leaves become resistant due to faster host growth than lower temperatures. This was the most likely explanation of the results obtained from inoculated plants exchanged between $20-30{ }^{\circ} \mathrm{C}$ (Xu, 1999). 
Our morphological results were in accordance with the researchers who reported that the spores of fungi present on the inoculated plants were similar in morphology compared to examine by diseased plants, fulfilling the Koch's postulates (Han et al., 2016). Prostrate knotweed (E. polygoni) is well known fungi distributed in the United States, Europe (United Kingdom, Czech Republic, Romania, Finland, and the former the Soviet Union), and China, Taiwan, Nepal, India (Lebeda et al., 2007) and Korea (Han et al., 2016). This study is in accordance with the investigations that powdery mildew was cosmopolitan and showed plant parasitic properties for angiosperm plants. Some species of E. polygoni are harmful specifically in agriculture and caused economic damage (Severoglu and Ozyigit, 2012); however, some may use as biological control agents (BCA's) on native and invasive weeds.

The Chinese climates vary from region to region with different ecological conditions and temperature fluctuates haphazardly resulted pathogen pressure can be increased. Our study was focused on prostrate knotweed (Polygonum aviculare L.), a plant parasitic powdery mildew (E. polygoni) investigated at roadsides, gardens and landscape range. This is a preliminary systematic study was conducted to identify powdery mildew in its conidial morphological states on prostrate knotweed and study its growth parameters compared to control. During field survey the infection of $E$. polygoni was observed on Rumex acetosa, Plantago asiatica, Syringa oblata and Taraxacum mongolicum which may become promising candidate for biological control agent (BCA's) in future.

\section{Conclusion}

Powdery mildew pathogen strain HMLAC226 is an important emerging parasitic agent of prostrate knotweed ( $P$. aviculare) widespread as serious disease throughout the world. The symptom of this disease appeared with favorable environmental conditions demonstrated significant damage to the leave tissues. Maximum $25-30{ }^{\circ} \mathrm{C}$ and minimum temperature $17-20^{\circ} \mathrm{C}$ along with $64-78 \%$ relative humidity are most conducive for pathogen establishment. According to the above analysis and findings, we encouraged researchers and ecologists to explore plant-pathogen interaction mechanism, resistance mechanism, host specificity test and genetic diversity in future.

Acknowledgements. This study was supported by the National Key R\&D Program of China (2017YFC1200101), the National Natural Science Foundation of China (31470575, 31670545 and 31971557).

Author's contributions. All authors have contributed equally to this paper.

Conflict of interests. All authors declare no conflict of interests.

\section{REFERENCES}

[1] Abkhoo, J. (2009): Powdery mildews causing fungi in Iran. - Mycopath 13: 51-55.

[2] Ahmad, S., Ali, H., Ur Rehman, A., Khan, R. J. Z., Ahmad, W., Fatima, Z., Abbas, G., Irfan, M., Ali, H., Khan, M. A. (2015): Measuring leaf area of winter cereals by different techniques: A comparison. - Pak. J. Life Soc. Sci 13: 117-125.

[3] Ahmed, M., Ji, M., Qin, P., Gu, Z., Liu, Y., Sikandar, A., Iqbal, M. F., Javeed, A. (2019): Phytochemical screening, total phenolic and flavonoids contents and antioxidant activities 
of Citrullus colocynthis L. and Cannabis sativa L. - Applied Ecology and Environmental Research 17: 6961-6979.

[4] Aldesuquy, H., Baka, Z., Mickky, B. (2014): Kinetin and spermine mediated induction of salt tolerance in wheat plants: Leaf area, photosynthesis and chloroplast ultrastructure of flag leaf at ear emergence. - Egyptian Journal of Basic and Applied Sciences 1: 77-87.

[5] ArcGis, E. (2013): Version 10.2. 0. - Environmental Systems Research Institute, Redlands.

[6] Batlla, D., Grundy, A., Dent, K. C., Clay, H. A., Finch-Savage, W. E. (2009): A quantitative analysis of temperature-dependent dormancy changes in Polygonum aviculare seeds. - Weed Research 49: 428-438.

[7] Bolund, P., Hunhammar, S. (1999): Ecosystem services in urban areas. - Ecological Economics 29: 293-301.

[8] Braun, U. (1987): A monograph of the Erysiphales (powdery mildews). - Beihefte zur Nova Hedwigia 89: 1-700.

[9] Braun, U. (2012): Taxonomic Manual of Erysiphales (Powdery Mildews). - CBS Biodiversity Series 11. CBS-KNAW Fungal Biodiversity Centre, Utrect.

[10] Braun, U., Takamatsu, S. (2000): Phylogeny of Erysiphe, Microsphaera, Uncinula (Erysipheae) and Cystotheca, Podosphaera, Sphaerotheca (Cystotheceae) inferred from rDNA ITS sequences - some taxonomic consequences. - Schlechtendalia 4: 1-33.

[11] Braun, U., Takamatsu, S. (2013): Phylogeny of Erysiphe, Microsphaera, Uncinula (Erysipheae) and Cystotheca, Podosphaera, Sphaerotheca (Cystotheceae) inferred from rDNA ITS sequences-some taxonomic consequences. - Schlechtendalia 4: 1-33.

[12] Braun, U., Cunnington, J. H., Brielmaier-Liebetanz, U., Ale-Agha, N., Heluta, V. (2003): Miscellaneous notes on some powdery mildew fungi. - Schlechtendalia 10: 91-95.

[13] Bugg, R., Ehler, L., Wilson, L. (1987): Effect of common knotweed (Polygonum aviculare) on abundance and efficiency of insect predators of crop pests. - Hilgardia 55: $1-52$.

[14] Carlile, M. J., Watkinson, S. C., Gooday, G. W. (2001): The Fungi. - Gulf Professional Publishing, Houston, TX.

[15] Chen, Wendy, Y., Jim, C. Y. (2008): Assessment and valuation of the ecosystem services provided by urban forests. - Ecology, Planning, and Management of Urban Forests, Springer.

[16] Cook, R. T. A., Inman, A. J., Billings, C. (1997): Identification and classification of powdery mildew anamorphs using light and scanning electron microscopy and host range data. - Mycological Research 101: 975-1002.

[17] Coquillat, M. (1951): Sur les plantes les plus communes a la surface du globe. Publications de la Société Linnéenne de Lyon 20: 165-170.

[18] Costea, M. T., François, J. (2005): The biology of Canadian weeds. 131. Polygonum aviculare L. - Canadian Journal of Plant Science 85: 481-506.

[19] Debaeke, P., Caussanel, J. P., Kiniry, J. R., Kafiz, B., Mondragon, G. (1997): Modelling crop: weed interactions in wheat with ALMANAC. - Weed Research 37: 325-341.

[20] Del, T., Peter (2010): Spontaneous urban vegetation: reflections of change in a globalized world. - Nature and Culture 5: 299-315.

[21] Flora of China. (2004): Polygonum aviculare (Linnaeus). - Species Plantarum. 1(5):362363 (1753).

[22] Francone, C., Pagani, V., Foi, M., Cappelli, G., Confalonieri, R. (2014): Comparison of leaf area index estimates by ceptometer and Pocket LAI smart app in canopies with different structures. - Field Crop Research 155: 38-41.

[23] Han, G. S., Kim, B. S., Choi, I. Y., Cho, S. E., Shin, H. D. (2016): First report of powdery mildew caused by Erysiphe polygoni on Homalocladium platycladum in Korea. - Plant Disease 100: 2170-2170.

[24] Hobbs, R. J., Higgs, E., Harris, J. A. (2009): Novel ecosystems: implications for conservation and restoration. - Trends in Ecology \& Evolution 24: 599-605. 
[25] Hossain, S. A. A. M., Wang, L., Chen, T., Li, Z. (2017): Leaf area index assessment for tomato and cucumber growing period under different water treatments. - Plant, Soil and Environment 63: 461-467.

[26] Koike, S., Gladders, P., Paulus, A. 2007. Vegetable Diseases: A Color Handbook. Academic Press. San Diego, California, USA.

[27] Lebeda, A., Mieslerová, B., Rybka, V., Sedlářová, M., Petrželová, I. (2007): First record of powdery mildew on Homalocladium platycladum in the Czech Republic. - Plant Pathology 56: 722-722.

[28] Ma, J. S., Yan, X. L., Shou, H. Y. (2013): The Checklist of the Chinese Invasive Plants. China Higher Education Press, Beijing.

[29] Mayer, D. G., Butler, D. G. (1993): Statistical validation. - Ecological Modelling 68: 2132.

[30] Meerts, P. (1995): Phenotypic plasticity in the annual weed Polygonum aviculare. Botanica Acta 108: 414-424.

[31] Meerts, P., Briane, J. P., Lefèbvre, C. (1990): A numerical taxonomic study of the Polygonum aviculare complex (Polygonaceae) in Belgium. - Plant Systematics and Evolution 173: 71-89.

[32] Miller, T. C., Gubler, W. D., Geng, S., Rizzo, D. M. (2003): Effects of temperature and water vapor pressure on conidial germination and lesion expansion of Sphaerotheca macularis f. sp. fragariae. - Plant Disease 87: 484-492.

[33] Nigussie, S. T., Amare, S. A., Manaye, M. M., Edget, M. B., Ashenafi, A. H., Girum, F. B., Tesfaye, B. H. (2017): Invasion and impacts of Xanthium strumarium in Borena Zone of Oromia Region, Ethiopia. - Journal of Coastal Life Medicine 5: 350-355.

[34] Peduto, F., Backup, P., Hand, E. K., Janousek, C. N., Gubler, W. D. (2013): Effect of high temperature and exposure time on Erysiphe necator growth and reproduction: revisions to the UC Davis Powdery Mildew Risk Index. - Plant Disease 97: 1438-1447.

[35] Pickett, S. T. A., Cadenasso, M. L., Grove, J. M., Groffman, P. M., Band, L. E., Boone, C. G., Burch, W. R., Grimmond, C. S. B., Hom, J., Jenkins, J. C. (2008): Beyond urban legends: an emerging framework of urban ecology, as illustrated by the Baltimore Ecosystem Study. - BioScience 58: 139-150.

[36] Pintye, A., Bereczky, Z., Kovács, G. M., Nagy, L. G., Xu, X., Legler, S. E., Váczy, Z., Váczy, K. Z., Caffi, T., Rossi, V. (2012): No indication of strict host associations in a widespread mycoparasite: grapevine powdery mildew (Erysiphe necator) is attacked by phylogenetically distant Ampelomyces strains in the field. - Phytopathology 102: 707716.

[37] Rcore, T. (2016): R: A Language and Environment for Statistical Computing. - R Foundation for Statistical Computing, Vienna, Austria. http://www.R-project.org.

[38] Rink, D. (2009): Wilderness: The nature of urban shrinkage? The debate on urban restructuring and restoration in Eastern Germany. - Nature and Culture 4: 275-292.

[39] Royo, E. A., Torra, J., Conesa, J. A., Forcella, F., Recasens, J. (2010): Modeling the emergence of three arable bedstraw (Galium) species. - Weed Science 58: 10-15.

[40] Severoglu, Z., Ozyigit, Ibrahim, I. (2012): Powdery mildew disease in some natural and exotic plants of Istanbul, Turkey. - Pak. J. Bot 44: 387-393.

[41] Takamatsu, S., Hirata, T., Sato, Y. (1998): Phylogenetic analysis and predicted secondary structures of the rDNA internal transcribed spacers of the powdery mildew fungi (Erysiphaceae). - Mycoscience 39: 441-453.

[42] Tottman, D. R., Wilson, B. J. (1990): Weed control in small grain cereals. In: Hance, R. J., Holly, K., eds. - Weed Control Handbook: Principles. Oxford, UK: Blackwell, 30-328.

[43] Tyrväinen, L., Pauleit, S., Seeland, K., de Vries, S. (2005): Benefits and Uses of Urban Forests and Trees. - In: Konijnendijk, C., Nilsson, K., Randrup, T., Schipperijn, J. (eds.) Urban Forests and Trees. Springer, Berlin. 
[44] Xu, X.-M. (1999): Effects of temperature on the length of the incubation period of rose powdery mildew (Sphaerotheca pannosa var. rosae). - European Journal of Plant Pathology 105: 13-21.

[45] You, J. F., He, Y. F., Yang, J. L., Zheng, S. J. (2005): A comparison of aluminum resistance among Polygonum species originating on strongly acidic and neutral soils. Plant and Soil 276: 143-151. 